\title{
EMPOWERMENT OF PRODUCTIVE ECONOMIC BUSINESS FOR THE POOR IN SERANG CITY
}

lis Ismawati ${ }^{1 *}$, Helmi Yazid ${ }^{2}$

${ }^{1 * 2}$ Faculty of Economics and Business, University of Sultan Ageng Tirtayasa

ismawati@untirta.ac.id ${ }^{\left.1^{*}\right)}$

\begin{abstract}
Abstrak
Pengabdian kepada masyarakat adalah bagaimana memberdayakan masyarakat miskin di perkotaan melalui upaya ekonomi produktif, identifikasi masalah Jumlah penduduk miskin cenderung meningkat, peluang usaha yang ada relatif terbatas, usaha ekonomi produktif yang belum optimal dan akses pasar yang terbatas untuk kelompok usaha.

Tujuan kegiatan tersebut adalah untuk menumbuhkan jiwa wirausaha bagi masyarakat miskin melalui pembentukan kelompok usaha bersama, memberdayakan potensi masyarakat miskin dalam meningkatkan pendapatan keluarga melalui peningkatan usaha ekonomi produktif.

Proses pemberdayaan masyarakat di desa dimulai dengan tahap pembentukan, kemudian pelaksanaan dan yang terakhir adalah tahap serah terima bantuan. permasalahan terkait faktor-faktor yang mempengaruhi dinamika kelompok usaha bersama di Desa Banjar, peningkatan usaha ekonomi produktif kelompok usaha bersama, lebih mengarah pada usaha catur untuk meningkatkan kualitas produk, efisiensi biaya produksi, perluasan pemasaran dan peningkatan skala usaha.
\end{abstract}

Kata kunci: Pemberdayaan, Wirausaha, Ekonomi

\begin{abstract}
Community service is how to empower the poor in urban areas through productive economic efforts, problem identification The number of poor people tends to increase, the existing business opportunities are relatively limited, productive economic businesses are not optimal and market access is limited for business groups.

The purpose of the activity is to foster an entrepreneurial spirit for the poor through the formation of joint business groups, to empower the potential of the poor in increasing family income through increasing productive economic enterprises.

The process of community empowerment in the village begins with the formation stage, then implementation and the last is the stage of handing over assistance. problems related to the factors that influence the dynamics of joint business groups in Banjar Village, increasing productive economic efforts of joint business groups, more directed to chess efforts to improve product quality, production cost efficiency, marketing expansion and business scale improvement.
\end{abstract}

Keywords: Empowerment, Entrepreneur, Economic 


\section{Introduction}

Empowerment is a concept to give people greater responsibility for how to do work. Empowerment will be successful if it is carried out by entrepreneurs, leaders and groups in a structured manner by building a good work culture. The concept of empowerment is related to the notion of community development and community-based development. Serang City consists of 6 sub-districts, which are further divided into a number of subdistricts. In the past, Serang was part of the Serang Regency area, then it was designated as an autonomous city on November 2, 2007. Serang City consists of: Serang, Cipocok Jaya, Curug, Kasemen, Taktakan, Walantaka. The problem are the number of poor people tends to increase, there are relatively limited business opportunities, productive economic business is not optimal yet, and limited market access for business groups. From the problems identified, it can be formulated that the problem to be solved in community service is how to empower the poor in urban areas through productive economic efforts.

The purpose of activities are fostering the spirit of entrepreneurship for the poor through the formation of joint business groups, empowering the potential of the poor in increasing family income through increasing productive economic enterprises. Activity Benefit provide business alternatives to the community, so as to improve family welfare. Other benefit is equipping the community to have an entrepreneurial spirit in developing productive economic enterprises.

According to (Todaro, 2011) economic development is a multidimensional process that involves a variety of fundamental changes in social structures, public attitudes, and national institutions such as accelerating growth, reducing inequality, and reducing poverty. Various empirical findings show that there is still marginalization of people's lives, especially the poor, both in urban and rural areas. In essence, according to Moeljarto (2011) poverty is not only a matter of welfare but there are six reasons that can be used as the basis for people to be said to be poor, namely: (1) poverty is a problem of vulnerability; (2) poverty means closed access to various opportunities for them to participate in the production process, or trapped in an exploitative production relationship with low rewards; (3) poverty is a matter of distrust, feelings of emotional and social impotence for decisions made by bureaucratic elites at various levels; (4) poverty also means spending all or most of the income for food consumption in limited quantity and quality so that consumption of nutrients is low which results in low production; (5) poverty is characterized by a low ratio, dependence due to large family dependents which results in low consumption so that it affects intelligence; and (6) poverty is also reflected in the culture that is passed down from one generation to another.

Alfian, Tan and Soemardjan (1980) said that there are two categories of measuring poverty levels, namely absolute poverty and relative poverty. Absolute poverty is a condition in which a person's income level is not sufficient to meet basic needs such as food, clothing, housing, health and education. Meanwhile, relative poverty is a calculation of poverty based on the proportion of income distribution in an area. This poverty is said to be relative because it is more related to the income distribution of social layers

Thus, discussing poverty is a complex issue and needs to be approached from various aspects, but to understand poverty objectively there are indicators that can be used as benchmarks for measurement. The World Bank sets a poverty line of $\$ 50$ per capita per year.

The Development of Productive Economic Enterprises (UEP) and Social Welfare 
Enterprises (UKS) through the Joint Business Group (KUBE) for the poor is one of the programs developed by the government through the social service.

Development of the KUBE Sejahtera Microfinance Institution which was established in every poor/remote sub-district to facilitate business capital for the poor KUBE-KUBE: in collaboration with PINBUK since 2003. Through KUBE it is hoped that the poor can develop their potential so that they can improve the standard of living of their families.

To overcome these problems, various solutions can be carried out as follows; provide an understanding of entrepreneurship as initial capital in developing a business. The form of activity is training on business motivation and entrepreneurship. Others solution is develop productive economic enterprises in the form of Joint Business Groups based on the group's potential.

The strategic target in this activity is the community belonging to the Family Towards Prosperity (KMS) located in Cipocok Jaya District, Serang City, which is spread over three villages. The number of training participants was 20 people consisting of men and women.

This activity would not have been possible without the involvement of several other parties. In this case, the Cipocok Jaya District, Serang City, Serang City, as the party that owns the area where PPM activities are to be carried out, provides support in this activity by providing a training place. In addition, the Serang City Social Service is expected to be able to provide support through programs related to empowering the poor through the establishment of KUBE.

\section{Implementation Method}

In order to achieve the objectives listed above, the following steps were taken;

1. Contacting the Copocok Sub-district Head to discuss the topics to be devoted, namely empowering productive economic enterprises for the poor and seeking data on the number of community members classified as poor as potential trainees

2. Organizing training, with the following materials:

a. Entrepreneurship

b. Finding business opportunities

c. Business management

d. Improvement of skills, in the form of training in making products that are tailored to the potential of community members, such as culinary and handicrafts.

\section{Result and Discussion}

To assess the success of this activity program are:

1. $80 \%$ of invited participants attended the training.

2. Implementation of all entrepreneurship training activities

3. $40 \%$ of participants were able to develop a productive economic business with assistance from the service team

4. Statement of satisfaction from training participants, and local government.

The purpose of entrepreneurship training is to gradually train participants to have entrepreneurial and business competencies, train entrepreneurs and businesses, train entrepreneurs to be able to act in establishing a proper business by taking advantage of opportunities that exist at certain times and in certain areas and develop human resources who are able to create job opportunities for himself or others according to the demands of development with the aim of motivating participants to improve their achievements in 
conducting studies, preparing business plan proposals and presenting presentations in front of financial institution or banking officials.

The general purpose of this training is to encourage more motivation to do business, as the specific objectives are:

1. Train participants gradually to have entrepreneurial and business competencies.

2. Train entrepreneurs to be able to act in establishing a proper business by taking advantage of the opportunities that exist at certain times and in certain areas.

3. Develop human resources who are able to create job opportunities for themselves and others according to the demands of development.

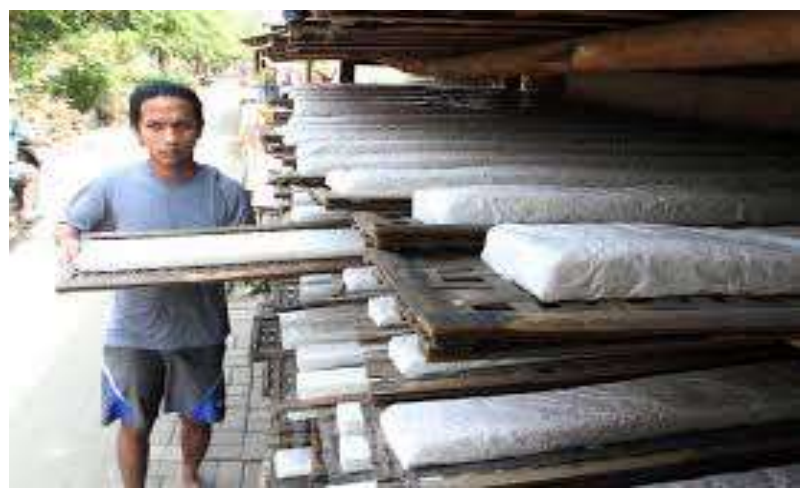

Figure 1. entrepreneurship training 1

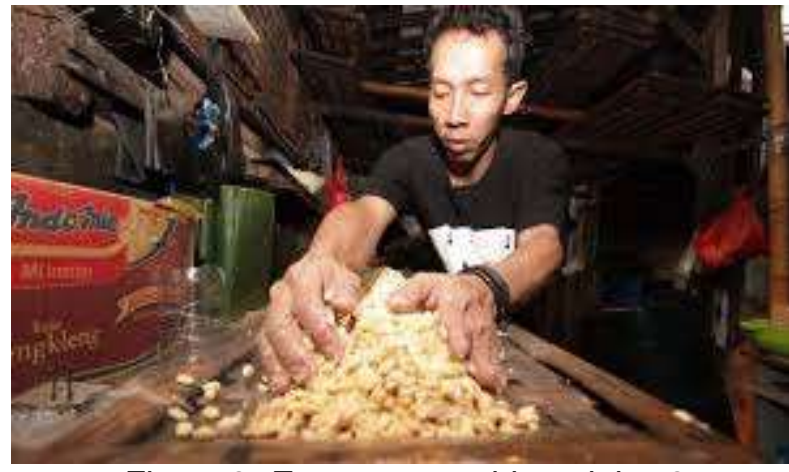

Figure 2. Entrepreneurship training 2

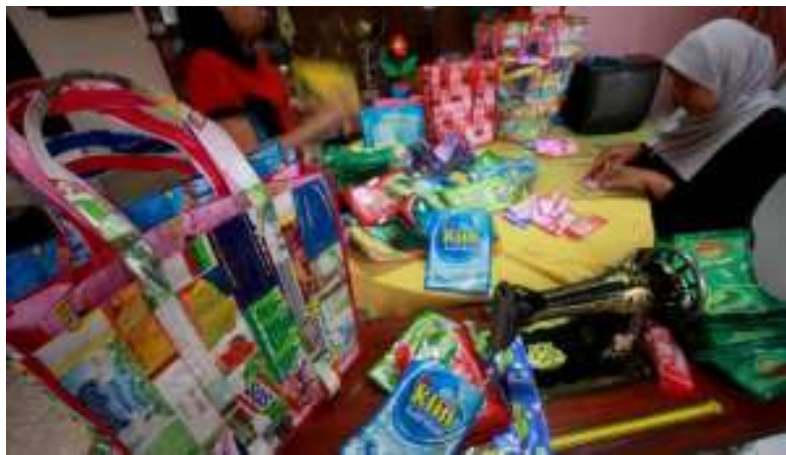

Figure 3. Entrepreneurship training 3 


\section{Conclusion}

Based on the studies that have been carried out on the Process of Empowering the Poor through the Institutional Joint Business Group (KUBE) in Banjar Agung Village, Cipocok Jaya District, Serang City, several conclusions were obtained: (1) The process of community empowerment in the village begins with the formation stage, then implementation and the last is the stage of handing over assistance. These three stages are still in the initial phase which means that empowerment comes from the government, the government to stimulate the community in Banjar Agung Village to be able to develop their capacity through joint business groups. the government, in this case the ministry and social services, both district and province, combines the paradigm of people centered development or community-centered development with the growth paradigm as a strategy used to empower the target community for empowerment in Banjar Agung Village. In the short term, the empowerment program is the realization of the fulfillment of the basic needs of the empowerment target community, while for the long term goal is to improve the quality and independence of the empowerment target community in productive economic efforts and institutions. (2) Meanwhile, there were many problems related to the factors that influence the dynamics of joint business groups in Banjar Agung Village, Cipocok Jaya District, the first was internal problems, namely the awareness of minority group members who were still unable to understand and carry out the group's goals, then the dualism of work carried out by field assistants, culture and the external environment of Banjar Agung Sub-district which is less supportive to carry out activities for developing group productive economic businesses and the government which still does not show quality in the intensity of supervision in the field. In the future, it is hoped that the government, both central and local, will carry out intensive training and preparation for empowerment target groups before assistance or empowerment capital is given so that there will be no more misuse of capital by groups that have been formed. Because in this case empowerment is considered as a continuous process, in developing the institutional capacity of the community, the target of empowerment or members of a joint business group should have the courage to express the problems experienced to field assistants, not the other way around. For this reason, field assistants here should be able to stimulate the community, especially in terms of finding a problem and also how to solve it. (3) Meanwhile, to increase the productive economic effort of the joint business group, more directed towards business chess, business chess, product quality improvement, production cost efficiency, marketing expansion and business scale improvement.

\section{Suggestion}

As for suggestions, there are several things that researchers need to convey regarding the empowerment process through a joint business group in Banjar Agung Village, Cipocok Jaya District, Serang City and also the factors that influence it, which are as follows: (1) In the process of forming a Joint Business Group (KUBE) or the process of introducing empowerment media (KUBE), the steps taken by the government have been very good, it's just that in Banjar Agung Village too many groups are formed, so this is very ineffective and efficient. In the future, it is hoped that the government, both central and local, will carry out intensive training and preparation for empowerment target groups before assistance or empowerment capital is given so that there will be no more misuse of capital by groups that have been formed. (2.) Because in this case empowerment is considered as a continuous 
process, in developing the institutional capacity of the community, the target of empowerment or members of a joint business group should have the courage to express the problems experienced to field assistants, not the other way around. For this reason, field assistants here should be able to stimulate the community, especially in terms of finding a problem and also how to solve it.

\section{References}

Allan, Tan, M.G., and Soemardjan, S, 1980, Structural Poverty, An Anthology. Jakarta: YIIS

Ellis, G.F.R. 1984. The Dimension of Poverty in Social Indicator Research Esmara, H. 1986. Planning and Development in Indonesia, Jakarta: Gramedia Kempton, J. 1995. Human Resource Management and Development. London:MacMillan Press Ltd

Huraera, Abu. 2008. Community Organization and Development. Community Based Development Models and Strategies. Bandung : Humanities, Education Book Publisher - Member of IKAPI.

Moeljanto, T. 1996. Development, Dilemmas and Challenges. Serang: Student Library

Todaro, Michael P. and Stephen C. Smith (2011). Economic Development, Edition 11. Jakarta Erlangga. 